J. Product. \& Dev., 20(3): 325 - 342(2015)

\title{
EFFECT OF BORON, COPPER AND HUMIC ACID TREATMENTS ON VEGETATIVE GROWTH, YIELD AND STORABILITY OF JERUSALEM ARTICHOKE TUBERS
}

\author{
M. M. Samy, Nagwa A. Mohamed and Mervat G. Abd El-Aziz \\ Potato and Vegetatively Propagated Vegetables Department, Hort. Res., \\ Institute, Egypt.
}

\section{ABSTRACT}

These experiments were carried out during two successive summer seasons of 2013 and 2014 on Jerusalem artichoke cv. Feusa. The plants were grown at Kaha Vegetables Res. Farm, Hort. Res. Inst., Agric. Res. Centre, under clay loam soil with using surface irrigation system, to study the effect of boron, copper and humic acid on vegetative growth, yield and its components, chemical constituents and storability of Jerusalem artichoke tubers. The experiment including 9 treatments (foliar spray with 70 and 140 ppm boron, 50 and $100 \mathrm{ppm}$ copper, 0.5 and $1 \mathrm{~g} / \mathrm{l}$ humic acid as foliar application and 0.5 and $1 \mathrm{~g} / \mathrm{l}$ humic acid as soil application beside of the control treatment ( spraying with water). The experiment was arranged in a randomized complete block design with three replicates.

The obtained results showed that the highest value of plant height was recorded by the plants which for sprayed with 50 or 100 ppm copper. While the plants which sprayed with $140 \mathrm{ppm}$ boron gave the highest number of main stems per plant. Application of humic acid 1 $\mathrm{g} / \mathrm{l}$ as soil application increased dry weight of foliage, number of tubers, yield per plant and total yield per feddan. Moreover, sprayed plants with 140 ppm boron treated plants with $1 \mathrm{~g} / \mathrm{l}$ humic acid as soil application produced more average tuber weight than the other tested treatments. Chemical composition (N, P, K, Total carbohydrates and inulin contents) of Jerusalem artichoke was significantly affected with application all treatments than control treatment. The results also confirmed that weight loss and decay percentage in Jerusalem artichoke tubers increased with prolongation of storage period.

In addition, the plants, which sprayed with copper or boron in both concentrations, gave the lowest values in weight loss and decay percentage in Jerusalem artichoke tubers during the storage period.

Conclusively, from the obtained data in this study, it can be recommended by using humic acid at soil for improve growth, number 
of tubers, yield per plant and total yield. On the other hand, foliar application of boron on Jerusalem artichoke plants increased average tuber weight. Also, foliar spray with copper or boron helps to storage the tubers and low rate of weight loss and decay.

Key words: Jerusalem artichoke, boron, copper, humic acid, storability, weight loss and decay percentage.

\section{INTRODUCTION}

Jerusalem artichoke (Helianthus tuberosus L.) is grown primarily for its edible tubers. Unlike most tubers, its tubers store carbohydrates as a polymer of fructose molecules called fructans (inulin) instead of starch. Inulin is effective in preventing the risk of insulin-dependent diabetes mellitus (type 2), blood cholesterol and heart disease, as well as, enhancing immunity (Orafti, 2005). Since inulin represents $80-90 \%$ of total carbohydrate content of the Jerusalem artichoke tubers, it makes the plant of great interest as raw material for inulin and fructose processing. Comparing with potato and chicory, Jerusalem artichoke contains more than four times higher content of sulphur amino acids. Such a great amount of sulphur amino acids in Jerusalem artichoke helps in connecting it in diet with legumes seeds, which are poor in those amino acids. This can have a special meaning in the countries where bean is the main source of protein as Barta and Pátkai (2007) reported.

Thus, Jerusalem artichokes is currently an important crop for production of healthy food, however, a few studies were carried out on it specially in Egypt; as it, is still considered one of the non-traditional vegetable crop. Since our soils having low organic matter content and high soil $\mathrm{pH}$ levels; application of humic acid, $\mathrm{B}$ and $\mathrm{Cu}$ in addition to essential major elements can play a good role in increasing the yield of Jerusalem artichoke, and improve its quality, as well as, storage ability.

Regarding the effect of boron, it is important for metabolism and growth of higher plants through its effect on cell elongation and cell division, protein metabolism, tissue differentiation and membrane permeability (Marschner, 2013).

Puzina (2004) showed that using boric acid caused an increase in tuber potato size and weight by increasing of cell diameter in the tuber perimedullary zone. El-Dissoky and Abdel-Kadar (2013) and Jafari-Jood et al. (2013) showed that spraying of boron significantly improved growth parameters of potato plants (plant height, number of leaves per plant and shoot weight) of potato plant as compared with control. Moreover, Marie and Toma (2011) reported that foliar application of $1.0 \mathrm{~kg} / \mathrm{ha}$ boron significantly increased a marketable yield with $61.8 \%$ and $66.3 \%$, tuber weight per plant with $60 \%$ and $59.4 \%$, number of tubers per plant with $21.869 \%$ and $22.967 \%$, average tuber 
weight with $33 \%$ and 31\%; also increased starch content in potato tubers. Similar results reported by El-Dissoky and Abdel-Kadar (2013) who stated that a significant increases in potato uptake of $\mathrm{N}, \mathrm{P}$ and $\mathrm{K}$. However, in the two previous studies, the significance of increment of B concentration in tubers was differed in the two studies correlated with the location and the variety.

Humic acid applications led to significant increase in plant growth and crop yield as a result of the improvement of soil organic matter content (Hafez, 2003 and El-Desuki, 2004). Humic acid increased potato tuber yield and quality (Verlinden et al., 2009, Mahmoud and Hafez, 2010 and Selim et al., 2011). Also, soil application of humic acid to sweet potato enhanced plant growth characteristics, total and marketable yield, and tuber root quality, as well as, reduced the weight loss and decay percentages (El Sayed Hameda et al., 2011).

As for Jerusalem artichoke, Eid (2013) stated that humic acid increased tuber yield, fresh and dry weight of shoot and enzymes activity.

In respect to copper, Cholewa (2008) revealed statistically significant increase in rapeseed yields with foliar of copper at $250 \mathrm{~g} / \mathrm{ha}$ and of the soil fertilization at $12 \mathrm{~kg} / \mathrm{ha}$. for oil quality, the foliar and pre-sowing fertilization with copper at 8 and $12 \mathrm{~kg} /$ ha led to a significant increase in the concentration of oil in seeds, a favorable tendency towards increased copper concentration in seeds. Foliar copper application produced a stronger effect on the concentration of this element and fat level in rape seed was more pronounced than soil $\mathrm{Cu}$ fertilization. Yao (2014) illustrated that, foliar spraying copper fertilizer significantly increased copper concentration in the pepper plant compared to spraying water.

Since tubers of Jerusalem artichoke have a thin and delicate skin and after harvest it permits rapid water loss (Danilcenko et al., 2008).

Therefore, the current study aimed to investigate the effect of boron, copper and humic acid on yield and storability of Jerusalem artichoke under Egyptian condition.

\section{MATERIAS AND METHODS}

The field experiment was carried out at the Experimental Vegetable Res. Farm of Kaha, Kalyoubia Governorate, Egypt during the two successive seasons of 2013 \& 2014 to study the effect of foliar spray with boron as boric acid (98\% B) and copper as cupper sulphate $(98 \% \mathrm{CuO})$ as well as humic acid foliar and soli application on growth, yield, tuber quality, chemical constituents and storability of Jerusalem artichoke (Helianthus tuberosus L.) $c v$. Feusa.

The site is located at an altitude of $21.1 \mathrm{~m}$ above sea level, latitude $30^{\circ} 16$ $\mathrm{N}$ and longitude $31^{\circ} 12^{\prime} \mathrm{E}$. with clay loam soil in texture. Chemical and physical 
Table 1. The physical and chemical properties of the experimental soil.

\begin{tabular}{|c|c|c|c|c|c|}
\hline \multirow{2}{*}{$\begin{array}{c}\text { Physical } \\
\text { Properties }\end{array}$} & \multicolumn{2}{|c|}{ Seasons } & \multirow{2}{*}{$\begin{array}{l}\text { Chemical } \\
\text { (available) }\end{array}$} & \multicolumn{2}{|c|}{ Seasons } \\
\hline & 2013 & 2014 & & 2013 & 2014 \\
\hline Clay \% & 62.50 & 60.20 & $\mathrm{~N}$ & 96.80 & 97.63 \\
\hline Silt \% & 17.80 & 20.40 & $\mathrm{P}$ & 5.55 & 4.68 \\
\hline Sand \% & 19.70 & 19.40 & $\mathrm{~K}$ & 212.12 & 215.46 \\
\hline Texture class & \multicolumn{2}{|c|}{ Clay loam } & pH (1- 2.5 & 7.50 & 7.42 \\
\hline
\end{tabular}

properties of the experimental soil are shown in Table 1. Soil chemical analysis was measured according to the procedures described by Jackson (1973).

Tubers were planted on $16^{\text {th }}$ and $19^{\text {th }}$ of April in both seasons, respectively. The experiment included nine treatments as follows:

$\mathrm{T} 1=$ Boron $70 \mathrm{ppm}$ (foliar application), T2=Boron $140 \mathrm{ppm}$ (foliar application), T3=Copper 50 ppm (foliar application), T4=Copper $100 \mathrm{ppm}$ (foliar application), T5= Humic acid $0.5 \mathrm{~g} / \mathrm{l}$ (foliar application), T6= Humic acid $1 \mathrm{~g} / \mathrm{l}$ (foliar application), T7= Humic acid $0.5 \mathrm{~g} / \mathrm{l}$ (soil application), $\mathrm{T} 8=$ Humic acid $1 \mathrm{~g} / \mathrm{l}$ (soil application), and $\mathrm{T} 9=$ Control (spraying plants with tap water). These treatments were arranged in a randomized complete block design with three replicates.

The source of boron as boric acid $98 \%$, copper as copper sulphate $98 \%$ and humic acid was taken from the commercial fertile of Humikey $85 \%$, which containing (humic acid $85 \%$, Fulvic acid $5 \%$ and Potassium humate $8 \%$ ).

The area of the experimental plot was $17.75 \mathrm{~m}^{2}$ consisting of 5 ridges $5 \mathrm{~m}$ in length and $0.71 \mathrm{~m}$ in width whereas; one row was left without planting as a guard ridge between plots to avoid overlapping filtration and foliar sprayed. Tubers (seed tubers) were planted $50 \mathrm{~cm}$ apart. Jerusalem artichoke tubers were obtained from Hort. Res. Inst. Potato and Vegetatively Propagated Vegetables Res. Dep. Ministry of Agric., Dokki, Giza.

All treatments were applied two times at 114 and 144 days after planting in both seasons. All other cultural practices were applied according to the recommendation of the Egyptian Ministry of Agriculture.

\section{Data recorded:}

\section{Vegetative growth characters:}

Vegetative growth characters were measured at 150 days after planting. Five plants from each treatment were chosen randomly to determine the average plant height, average number of main stems per plant, average number of lateral branches per plant, and foliage dry weight. 


\section{Yield and its components:}

Yield determinations were recorded at harvesting time on $30^{\text {th }}$ November and $5^{\text {th }}$ December in the first and second seasons respectively. It included number of produced tuber roots per plant, average tuber weight $(\mathrm{g})$, tuber yield per plant $(\mathrm{kg})$ and total yield (ton/fed.).

\section{Chemical constituents:}

- Dry matter percentage: it was determined in 100 grams of a random tuber roots.

- Total carbohydrates were determined colorimetrically as gram of glucose $/ 100 \mathrm{~g}$ dry weight of tubers roots according the methods described by James (1995).

- Total nitrogen was determined according the method described by Koch and Mc Meckin (1924) using micro-kjeldahl apparatus, while phosphorus content was determined according to Troug and Meyer (1939); furthermore, potassium percentage was determined by using Flame photometer according to Brown and lilleland (1946).

- Tuber inulin concentration was determinate according to (Winton and Winton, 1958).

\section{Storage experiment:}

Jerusalem artichoke tubers were harvested on 15 November and then transported immediately to the laboratory of postharvest, Horticulture Research Institute. Tubers were sorted out and all the defected tubers were discarded and then packed in perforated bags $(15 \mu \mathrm{m})$ thickness. Three replicates were prepared for each treatment in addition to control; each replicate weighed approximately $(2.50) \mathrm{kg}$, and placed in carton boxes $(30 \times 20 \times 10 \mathrm{~cm})$. All treatments were stored at $\left(3{ }^{\circ} \mathrm{C}\right)$ degree and $\mathrm{RH} 90-95$ $\%$. Complete randomized design was adopted. All replicates were examined every month for weight loss and decay percentage, until 3 months ( 90 days).

\section{The following data were recorded}

1.Weight loss percentage was estimated according to the following equation: Weight loss \% = initial tuber weight - tuber weight at sampling date / initial tuber weight $* 100$.

2.Decay percentage was estimated as the number of decayed tubers / total count of tubers $\mathrm{x} 100$.

\section{Statistical analysis:}

Recorded data were subjected to the statistical analysis of variance according to Snedecor and Cochran (1980), and means separation were done according to LSD at $5 \%$ level. 


\section{RESULTS AND DISCUSSIONS}

\section{Vegetative growth parameters:}

Results shown in Table (2) revealed that all treatments had a positive effect on vegetative growth parameters ( plant height, number of main stems/plant, number of lateral branches/plant and foliage dry weight / plant) of Jerusalem artichoke plants in the two tested growing seasons. As regard to plant height, the maximum values were detected for spraying copper (50 or 100 ppm), as well as foliar application of boron at $140 \mathrm{ppm}$ without any significant between them. These increments were significant as compared to the control in both season. The same data presented in Table (2) indicate that foliar spray of boron concentration at $140 \mathrm{ppm}$ gave the highest number of main stems per plant in the two investigated seasons. This results was significant comparing only with humic acid soil addition at $0.5 \mathrm{~g} / \mathrm{L}$ in the first season while, it was significant with compared to all treatments in the second season except the soil addition of humic acid at $1 \mathrm{~cm} / \mathrm{L}$. This positive effect of $\mathrm{B}$ application may be attributed to B roles in cell wall synthesis, cell division, cell development, auxin metabolism as mentioned by Mengel and Kirkby (1978). These results are in agreement with those obtained by El-Dissoky and Abdel-Kadar (2013) and Jafari-Jood et al., (2013). Moreover, results in Table (2) show that spraying of copper at $100 \mathrm{ppm}$ significantly increased the number of lateral branches compared to the control in the two tested seasons. However, all treatments; except soil application of humic acid at $0.5 \mathrm{~g} / \mathrm{L}$, proved to be significantly effective in increasing the lateral branches number in the second season. Improvement of plant growth resulted from copper foliar spray could be due its importance for cell wall lignification; as lignification weakened lead to wilting (impaired water transport) characteristics of distortion of young leaves, bending and twisting of stems and twigs in cereals and vice versa as reported by Graham (1983).

Data presented in Table (2) clearly indicate that soil application of humic acid (soil application) at $1 \mathrm{~g} / \mathrm{L}$ appeared superiority in foliage dry weight formation per plant. Significant decrement in foliage dry weight per plant was exhibited for the control treatment all over the all tested treatments in the two investigated seasons. These presented results are in accordance with those obtained by (Hafez, 2003 and El-Desuki, 2004).

Regarding the effect of different treatments on foliage dry weight, the data in the same Table show that, the plants which treated with humic acid at 1 $\mathrm{g} / \mathrm{l}$ as soil application significantly increased foliage dry weight / plant in both seasons without significant differences with boron at $140 \mathrm{ppm}$ in the first season only. 
Table 2. Effect of some treatments on plant growth of Jerusalem artichoke plant after 150 days from planting, during 2013 and 2014 seasons.

\begin{tabular}{|c|c|c|c|c|}
\hline \multirow[t]{2}{*}{ Treatments } & $\begin{array}{l}\text { Plant height } \\
(\mathrm{cm})\end{array}$ & $\begin{array}{c}\text { Number of } \\
\text { main stem/ } \\
\text { plant }\end{array}$ & $\begin{array}{c}\text { Number of lateral } \\
\text { branches/ plant }\end{array}$ & $\begin{array}{c}\text { Foliage dry } \\
\text { weight }(\mathrm{g} / \text { plant })\end{array}$ \\
\hline & \multicolumn{4}{|c|}{ First season } \\
\hline T1 & 247.33 & 6.3 & 62.67 & 512.47 \\
\hline $\mathbf{T 2}$ & 251.33 & 7.7 & 67.67 & 552.78 \\
\hline T3 & 252.33 & 5.67 & 61.67 & 450.25 \\
\hline T4 & 255.00 & 6.33 & 69.67 & 470.42 \\
\hline T5 & 221.00 & 6.00 & 54.33 & 478.43 \\
\hline T6 & 231.33 & 7.33 & 61.33 & 550.18 \\
\hline T7 & 218.00 & 5.00 & 53.00 & 513.96 \\
\hline T8 & 229.67 & 7.00 & 59.00 & 554.24 \\
\hline T9 & 203.67 & 5.67 & 48.67 & 412.14 \\
\hline \multirow[t]{2}{*}{$\begin{array}{l}\text { L.S.D. at 5\% } \\
\text { significant level }\end{array}$} & 27.30 & 2.64 & 20.39 & 4.10 \\
\hline & \multicolumn{4}{|c|}{ Second season } \\
\hline T1 & 237.33 & 6.67 & 58.33 & 450.42 \\
\hline $\mathrm{T} 2$ & 245.33 & 8.33 & 63.67 & 498.14 \\
\hline T3 & 246.33 & 6.00 & 56.67 & 424.02 \\
\hline $\mathrm{T} 4$ & 250.67 & 6.67 & 66.67 & 465.48 \\
\hline $\mathrm{T} 5$ & 217.00 & 6.00 & 50.00 & 442.96 \\
\hline T6 & 231.00 & 6.33 & 54.33 & 514.56 \\
\hline $\mathrm{T} 7$ & 208.67 & 5.67 & 48.00 & 452.84 \\
\hline T8 & 228.00 & 7.33 & 53.00 & 562.45 \\
\hline T9 & 199.33 & 5.33 & 44.67 & 408.54 \\
\hline L.S.D. at $5 \%$ level & 18.61 & 1.48 & 4.24 & 4.51 \\
\hline \multicolumn{5}{|c|}{$\mathrm{T} 1=$ Boron $(70 \mathrm{ppm}$, foliar $)$} \\
\hline \multirow{2}{*}{\multicolumn{5}{|c|}{$\begin{array}{l}\mathrm{T} 4=\text { Copper }(100 \mathrm{ppm}, \text { foliar }) \\
\mathrm{T} 7=\text { Humic acid }(0.5 \mathrm{~g} / \mathrm{L}, \text { soil })\end{array}$}} \\
\hline & & nic acid $(1 \mathrm{~g} / \mathrm{L}$, & $\mathrm{T} 9=$ Spraying with & water (Control) \\
\hline
\end{tabular}

In addition, effects of humic acid containing fertilizers on plant yield and nutrient uptake depend on humic acid concentration, application type and plant species (Chen and Aviad, 1990).

Boron is important for metabolism and growth of higher plants in cell elongation and cell division, protein metabolisms, tissue differentiation, membrane permeability, pollen germination and pollen tube growth (Marschner, 2013).

\section{Yield and its components at harvest time:}

Regarding the total yield and its components at harvest time, soil application of humic acid was positively effective. In this concern, the highest total yield per plant and number of tubers/ plant were recorded when treated plants with humic acid at $1 \mathrm{~g} / \mathrm{l}$ as soil application in both 
season and without significant differences between foliar spray of boron at $140 \mathrm{ppm}$ regarding yield/ plant in the first season While control treatment recorded the lowest yield / plant in both seasons.

The increment in yield might be due to the stimulation of plant growth by humic acid through increasing cell division, as well as optimization uptake of nutrients and water (Chen et al., 2004). Also, Humic acid applications led to significant increase in soil organic matter content and improve plant growth and crop yield (Erik et al., 2000; Hartwigson and Evans, 2000; Hafez, 2003; El-Desuki, 2004). Moreover, humic acid stimulate the soil microorganisms (Qualls, 2004). Furthermore, Abd-ElKareem (2007) reported that bean plants treated with humic acid induced resistance against root rot and Alternaria leaf spot in addition to increase bean yield under field conditions. Previous studies revealed that humic acid increased tuber yield of Jerusalem artichoke (Eid, 2013). Furthermore, boron increased potato tuber yield by $17.39 \%$ (El-Dissoky and AbdelKadar, 2013).

According to Reisenauer et al. (1973) Boron is also probably more important than any other micronutrients in obtaining high quality and crop yields. They revealed that for soils that having low organic matter content and high soil $\mathrm{pH}$ levels, application of $\mathrm{B}$ in addition to essential major elements can play a good role in increasing the yield of potato.

Regarding the average tuber weight, the same data illustrated in Table (3) clearly indicate that foliar spray of humic acid at $1 \mathrm{~g} / \mathrm{l}$ produced more average tuber weight in both seasons without any significant differences between the plants which sprayed with boron at $140 \mathrm{ppm}$ in the second season . These results were in agreement with those reported by El-Dissoky and Abdel-Kadar (2013) who found that average weight of tubers increased at foliar spray of $60 \mathrm{mg} / 1$ boron.

As for the effect of different treatments on total yield, the data in indicated that, there were significant differences between the most tested treatments and control treatment in both seasons (Table 3). The highest total yield/ feddan ( 15.107 and 16.132 ton/fed. ) were recorded by the plants which received humic acid at $1 \mathrm{~g} / \mathrm{l}$ as soil application in the $1^{\text {st }}$ and $2^{\text {nd }}$ seasons, respectively , followed by the plants which received $1 \mathrm{~g} / \mathrm{l}$ as foliar application ( 14.773 and 15.662 ton/fed.) in the $1^{\text {st }}$ and $2^{\text {nd }}$ seasons, respectively. While, the lowest values of total yield/fed. were recorded with the plants received water only ( 8.471 and 11.626 ton/fed.) . The relative increases in total yield regarding the application of humic acid at $1 \mathrm{~g} / \mathrm{l}$ as soil application were about (77 and $39 \%$ ) followed by the treated plants with humic acid at $1 \mathrm{~g} / \mathrm{l}$ as foliar spray (74 and 35\%) than control treatment 
Table 3. Effect of some treatments on yield and its components at harvest time during 2013 and 2014 seasons.

\begin{tabular}{|c|c|c|c|c|c|c|}
\hline \multirow[t]{2}{*}{$\begin{array}{c}\text { Treatment } \\
\text { groups }\end{array}$} & $\begin{array}{c}\text { Yield/plant } \\
(\mathrm{kg})\end{array}$ & $\begin{array}{c}\text { Number } \\
\text { of tubers } \\
\text { /plant }\end{array}$ & $\begin{array}{c}\text { Average } \\
\text { tuber } \\
\text { weight }(\mathrm{g})\end{array}$ & $\begin{array}{c}\text { Total } \\
\text { yield / } \\
\text { fed. } \\
\text { (ton) }\end{array}$ & $\begin{array}{c}\text { Relative } \\
\text { increases } \\
\text { in total } \\
\text { yield }(\%)\end{array}$ & $\begin{array}{c}\text { Dry } \\
\text { matter } \\
(\%)\end{array}$ \\
\hline & \multicolumn{6}{|c|}{ First Season } \\
\hline $\mathrm{T} 1$ & 1.856 & 60.87 & 29.087 & 11.690 & & 17.32 \\
\hline $\mathrm{T} 2$ & 2.120 & 54.73 & 35.637 & 13.813 & & 22.29 \\
\hline T3 & 1.480 & 55.46 & 26.733 & 11.453 & & 21.35 \\
\hline $\mathrm{T} 4$ & 1.863 & 63.12 & 29.610 & 13.160 & & 20.45 \\
\hline $\mathrm{T} 5$ & 1.766 & 70.41 & 26.813 & 13.257 & & 20.63 \\
\hline T6 & 1.830 & 59.97 & 38.650 & 14.773 & & 22.11 \\
\hline $\mathrm{T} 7$ & 1.924 & 67.52 & 29.090 & 13.577 & & 21.71 \\
\hline T8 & 2.122 & 71.09 & 28.943 & 15.017 & & 22.47 \\
\hline T9 & 1.303 & 60.66 & 27.750 & 8.473 & & 23.15 \\
\hline \multirow{2}{*}{$\begin{array}{l}\text { L.S.D. at 5\% } \\
\text { significant level }\end{array}$} & 0.135 & 1.01 & 1.79 & 1.831 & & 1.29 \\
\hline & \multicolumn{6}{|c|}{ Second Season } \\
\hline $\mathrm{T} 1$ & 2.660 & 72.47 & 32.470 & 14.821 & & 16.01 \\
\hline $\mathrm{T} 2$ & 2.980 & 59.27 & 46.630 & 15.488 & & 24.09 \\
\hline T3 & 2.300 & 60.87 & 37.787 & 13.606 & & 21.89 \\
\hline $\mathrm{T} 4$ & 2.710 & 75.40 & 34.960 & 15.005 & & 19.06 \\
\hline T5 & 2.350 & 79.93 & 33.330 & 15.384 & & 20.9 \\
\hline T6 & 2.630 & 65.13 & 46.607 & 15.662 & & 23.93 \\
\hline $\mathrm{T} 7$ & 2.730 & 77.20 & 35.233 & 15.432 & & 22.47 \\
\hline T8 & 3.120 & 108.50 & 31.663 & 16.132 & & 24.39 \\
\hline T9 & 2.060 & 65.67 & 32.280 & 11.626 & & 26.67 \\
\hline $\begin{array}{l}\text { L.S.D. at 5\% } \\
\text { level }\end{array}$ & 0.084 & 1.28 & 1.20 & 0.877 & & 1.89 \\
\hline \multicolumn{7}{|c|}{$\mathrm{T} 1=$ Boron $(70 \mathrm{ppm}$, foliar $) \quad \mathrm{T} 2=$} \\
\hline $\begin{array}{l}\mathrm{T} 4=\text { Copper }(100 \\
\mathrm{T} 7=\text { Humic acid }\end{array}$ & $\begin{array}{ll}\text { foliar) } & \mathrm{T} 5= \\
\mathrm{L} \text {, soil) } & \mathrm{T} 8=\end{array}$ & $\begin{array}{l}\text { mic acid (0 } \\
\text { Imic acid (1 }\end{array}$ & $\begin{array}{l}\text { L, foliar) } \\
\text {, soil ) }\end{array}$ & $\begin{array}{l}\text { T6 }=\text { Humi } \\
\text { T9 }=\text { Spray }\end{array}$ & $\begin{array}{l}\text { cid }(1 \mathrm{~g} / \mathrm{L} \text {, foli } \\
\text { with tap wate }\end{array}$ & r) \\
\hline
\end{tabular}

in the $1^{\text {st }}$ and $2^{\text {nd }}$ seasons, respectively.

Dry matter percentage resulted from foliar boron application at 70 ppm was significantly the lowest value in the two tested seasons (Table 3). Control treatment had the highest dry matter percentage followed by each of boron foliar spray at $140 \mathrm{ppm}$, Humic acid spray at $1 \mathrm{~g} / \mathrm{L}$ and soil humic acid application at $1 \mathrm{~g} / \mathrm{L}$ with no significant difference among them in the first season. The increase in dry matter percentage in control treatment of Jerusalem artichoke tubers might be attributed to reduction in moisture content. Bari et al., (2001) showed that application of $1.1 \mathrm{~kg} \mathrm{~B} / \mathrm{ha}$ from borax increased potato yield, number of tubers/ha, as well as, fresh and dry weight of tubers yield. Humic acid stimulation plant growth through increasing cell division, as well as, optimized uptake of nutrients and water (Chen et al., 2004). Moreover, humic acid stimulated the soil microorganisms (Qualls, 2004). 
Furthermore, these findings are in agreement with those of Puzina (2004) and Marie and Toma (2011).

\section{Chemical composition of Jerusalem artichoke:}

Chemical composition percentages of Jerusalem artichoke tubers were calculated as dry weight (Table 4). Data showed that, chemical composition of $\mathrm{N}, \mathrm{P}, \mathrm{K}$, total carbohydrates and inulin contents were positively affected with all tested treatments compared to the control. In this concern, generally, the maximum increments of nitrogen, phosphorus and potassium were detected for soil addition of humic acid at $1 \mathrm{~g} / \mathrm{L}$ or with sprayed plants with $140 \mathrm{ppm}$ boron in most cases at both growing seasons. The same results were recorded by El-Shabrawy et al. (2010) who found that nitrogen, phosphorus and potassium contents were significantly influenced by soil application of humic acid. These results may support the suggestion of the stimulatory effect of humic acid on root growth and its uptake of nutrients (Liu et al., 1998; Zhang et al., 2003; Awad and El-Ghamry 2007). In this connection, humic acid stimulated capacity of action exchange as well as cell permeability of capillaries, leading to increase nutrient availability, enable better uptake of nutrients and act as plant growth promoters (O’Donnell, 1973; Malcolm and Vaughan, 1979).

Data also, show clearly that all treatments, i.e., boron, copper and humic acid enhanced boron in tubers, while spraying Jerusalem artichoke plants with boron gave the highest significant increase in boron content of the tubers compared to the other treatments in both growing seasons.

Concerning the effect of spraying Jerusalem artichoke plants with copper, data in Table (4) emphasized that copper spray significantly increased copper concentration in tubers compared to other treatments in both growing seasons, in generally, the lowest values were obtained when spraying Jerusalem artichoke plants by tap water (control treatment). In this respect, Yao (2014) stated that copper concentration increased significantly when foliar application with copper was used in pepper plants.

\section{Storage experiment:}

\section{Weight loss percentage:}

Data in Figure (1) show clearly that percentage of weight loss in Jerusalem artichoke tubers increased with prolonging storage period in both seasons.

The decrease in fresh weight of Jerusalem artichoke tubers might be attributed to the loss in moisture through transpiration and loss in dry matter content through respiration (Wills et al., 1981). 
Table 4. Effect of some treatments on N, P, K, total carbohydrates, inulin, copper and boron contents during 2013 and 2014 seasons.

\begin{tabular}{|c|c|c|c|c|c|c|c|}
\hline \multirow[t]{2}{*}{$\begin{array}{l}\text { Treatment } \\
\text { groups }\end{array}$} & $\mathbf{N} \%$ & P \% & K \% & $\begin{array}{c}\text { Total } \\
\text { carbohydrates } \\
\%\end{array}$ & $\underset{(\%)}{\text { Inulin }}$ & $\begin{array}{c}\text { Copper } \\
(\mathrm{mg} / \mathrm{kg} \\
\mathrm{D} . \mathrm{W})\end{array}$ & $\begin{array}{c}\begin{array}{c}\text { Boron } \\
(\mathrm{mg} / \mathrm{kg}\end{array} \\
\text { D.W) }\end{array}$ \\
\hline & \multicolumn{7}{|c|}{ First Season } \\
\hline $\mathrm{T} 1$ & 1.122 & 0.341 & 2.950 & 49.540 & 20.087 & 14.771 & 7.970 \\
\hline $\mathrm{T} 2$ & 1.411 & 0.356 & 3.120 & 50.607 & 28.433 & 15.627 & 9.413 \\
\hline T3 & 1.320 & 0.314 & 3.025 & 48.897 & 16.120 & 16.608 & 6.260 \\
\hline $\mathrm{T} 4$ & 1.631 & 0.327 & 2.900 & 49.083 & 17.563 & 17.305 & 6.843 \\
\hline T5 & 1.111 & 0.308 & 2.660 & 50.053 & 16.930 & 15.486 & 6.205 \\
\hline T6 & 1.520 & 0.324 & 2.890 & 50.153 & 18.647 & 16.430 & 6.282 \\
\hline $\mathrm{T} 7$ & 1.320 & 0.338 & 2.765 & 49.760 & 18.463 & 14.248 & 6.846 \\
\hline $\mathrm{T} 8$ & 1.712 & 0.382 & 3.238 & 50.220 & 19.093 & 15.009 & 7.645 \\
\hline T9 & 1.079 & 0.279 & 2.555 & 48.313 & 13.600 & 12.024 & 6.073 \\
\hline \multirow{2}{*}{$\begin{array}{l}\text { L.S.D. at } \\
\text { 5\% level }\end{array}$} & 0.05 & 0.067 & 0.275 & 1.195 & 0.739 & 0.360 & 0.022 \\
\hline & \multicolumn{7}{|c|}{ Second Season } \\
\hline $\mathrm{T} 1$ & 1.868 & 0.320 & 2.905 & 50.703 & 26.480 & 15.667 & 8.341 \\
\hline $\mathrm{T} 2$ & 1.986 & 0.331 & 3.045 & 52.610 & 30.177 & 17.207 & 10.017 \\
\hline T3 & 1.948 & 0.340 & 3.025 & 46.300 & 15.940 & 19.190 & 7.150 \\
\hline $\mathrm{T} 4$ & 2.125 & 0.338 & 3.065 & 46.427 & 23.330 & 20.357 & 7.217 \\
\hline T5 & 1.911 & 0.310 & 3.065 & 48.903 & 21.167 & 15.253 & 6.407 \\
\hline T6 & 2.055 & 0.342 & 3.125 & 48.380 & 25.757 & 16.347 & 6.433 \\
\hline $\mathrm{T7}$ & 1.985 & 0.344 & 2.910 & 49.237 & 23.600 & 14.373 & 7.117 \\
\hline $\mathrm{T} 8$ & 2.131 & 0.390 & 3.120 & 49.740 & 26.300 & 16.333 & 8.211 \\
\hline T9 & 1.616 & 0.266 & 2.810 & 44.193 & 15.040 & 13.463 & 6.402 \\
\hline $\begin{array}{l}\text { L.S.D. at } \\
5 \% \text { level }\end{array}$ & 0.005 & 0.056 & 0.234 & 4.817 & 0.893 & 0.442 & 0.074 \\
\hline \multirow{2}{*}{\multicolumn{3}{|c|}{$\begin{array}{l}\mathrm{T} 1=\text { Boron }(70 \mathrm{ppm}, \text { foliar }) \\
\mathrm{T} 4=\text { Copper }(100 \mathrm{ppm}, \text { foliar })\end{array}$}} & Boron & ppm, foliar) & $\mathrm{T} 3=\mathrm{C}$ & $50 \mathrm{ppr}$ & \\
\hline & & & Humic & $\mathrm{d}(0.5 \mathrm{~g} / \mathrm{L}$, foliar $)$ & $\mathrm{T} 6=\mathrm{Hu}$ & $\operatorname{acid}(1 \mathrm{~g} / \mathrm{L}$ & ar) \\
\hline \multicolumn{3}{|c|}{$\mathrm{T} 7=$ Humic acid $(0.5 \mathrm{~g} / \mathrm{L}$, soil $)$} & Humic & $\mathrm{d}(1 \mathrm{~g} / \mathrm{L}$, soil $)$ & $\mathrm{T} 9=\mathrm{Sp}$ & g with tap & er(Control) \\
\hline
\end{tabular}

Regarding the effect of treatments, foliar copper spray surpasses the other treatments in minimizing tubers weight loss percentage during storage ( T3 and T4).

\section{Decay percentage:}

A gradually and continuous increase in percentage of decay was noticed till the end of storage period in both seasons (Figure 2). While, foliar spray of copper gave the lowest values in weight loss and decay percentage in Jerusalem artichoke tubers during the storage period in both seasons. These results are in harmony with those obtained by El-Zohiri and Youssef (2015) who demonstrated that boron foliar application on Jerusalem artichoke plants caused the lowest weight loss and decay percentage of tubers. 

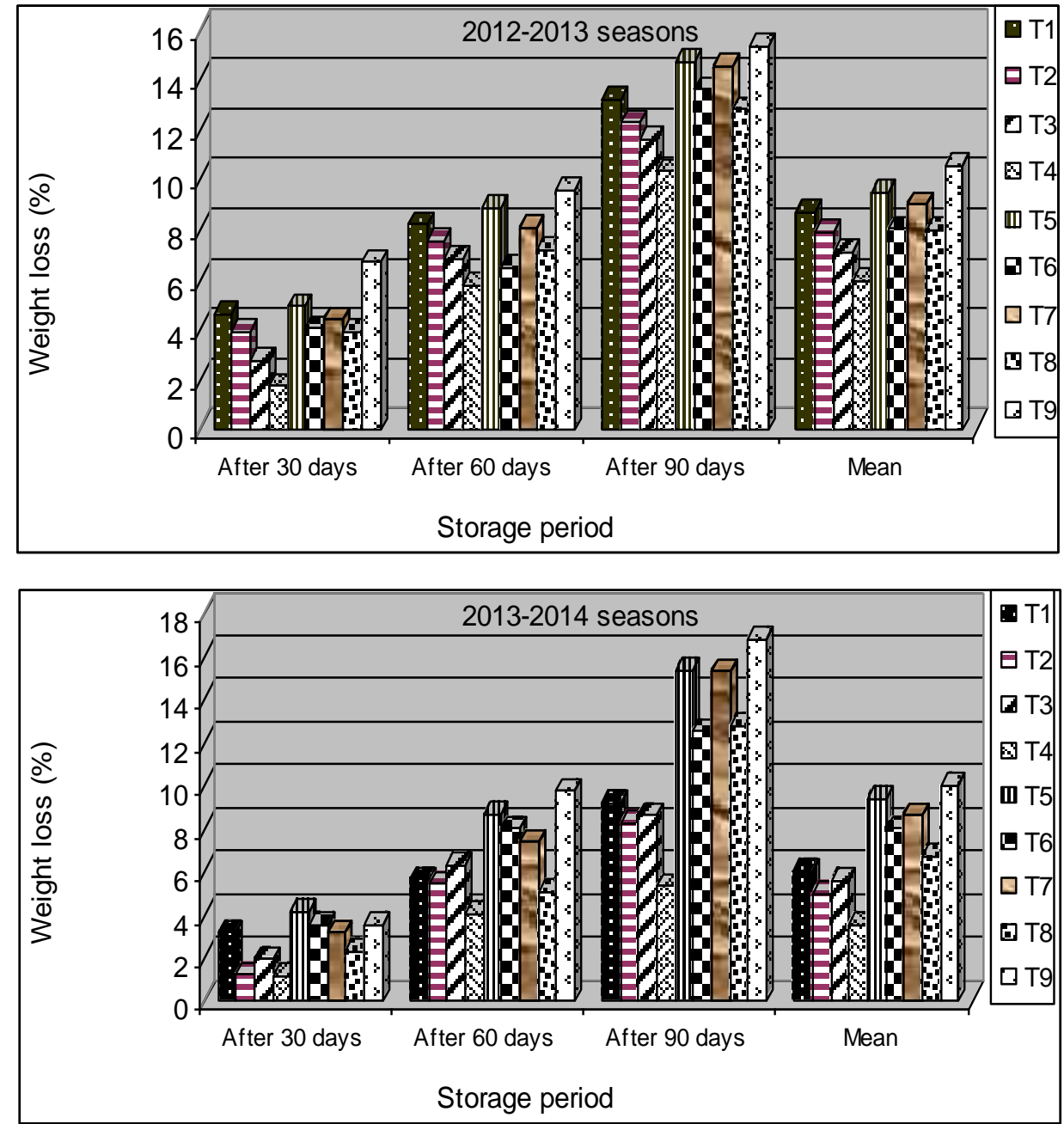

Figure 1. Effect of treatments on weight losses percentage of Jerusalem artichoke tubers in two growing seasons.

The decay could be due to the continuous chemical and biochemical changes happened in vegetable and fruits such as moisture concentration and transformation of complex compounds to simple forms of more liability to fungal infection such as solid protection to the soluble pectin form (Wills et al., 1981). Moreover, increasing cell wall and rising the capability of cells to resist wilting (Graham, 1983). Furthermore, Mortvedt et al. (1991) stated that in $\mathrm{Cu}$ deficient soil, root $\mathrm{Cu}$ concentrations are low and that such roots are sensitive to fungal and bacterial attack. 

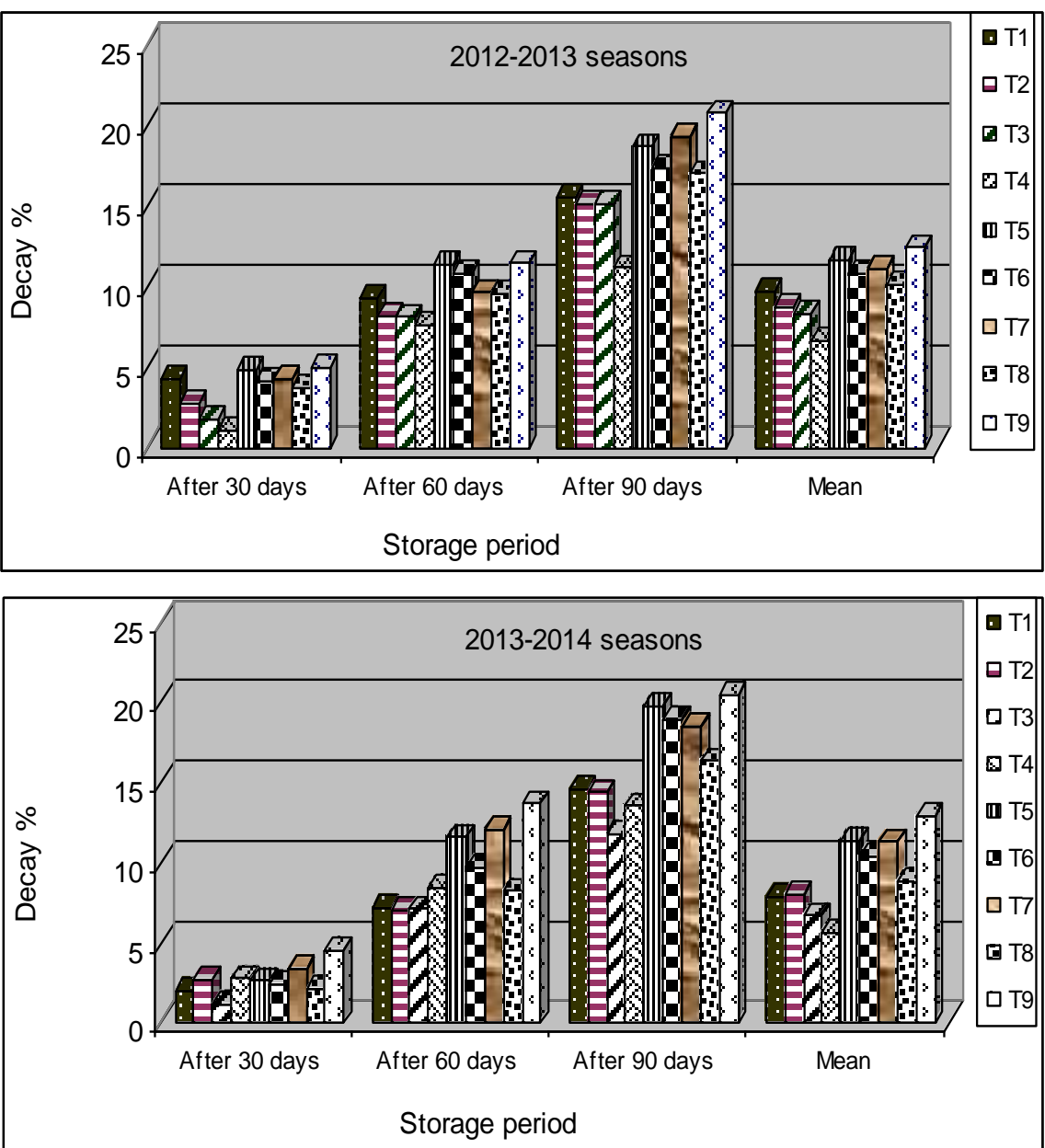

Figure 2. Effect of treatments on decay percentage of Jerusalem artichoke tubers in two growing seasons

Conclusively, from the obtained data in this study, it can be recommended by using humic acid at soil for improve growth, number of tubers, yield per plant and total yield. On the other hand, foliar application of boron on Jerusalem artichoke plants increased average tuber weight. Also, foliar spray with copper or boron helps to storage the tubers and low rate of weight loss and decay. 


\section{REFERENCES}

Abd-El-Kareem, F. (2007). Induced resistance in bean plants against root rot and Alternaria leaf spot diseases using biotic and abiotic inducers under field conditions. Research J. of Agricultural and Biological Science, 3(6): 767-774.

Awad, El.M.M. and A.M. El-Ghamry (2007). Effect of humic acid effective microorganisms (EM) and magnesium on potato in clay soil. J. Agric. Sci. Mansoura Univ., 32(9): 7629-7639.

Bari, M.S., M.G. Rabbani, M.S. Rahman, M.J. Islam and A.T. Hoque (2001). Effect of zinc, boron, sulphur and magnesium on the growth and yield of potato. Pakistan J. of Biological Sci., 4(9): 1090-1093.

Barta, J and G.Y, Pátkai (2007). Chemical composition and storability of Jerusalem artichoke tubers. Acta Alimentaria, 36:257-67.

Brown, I. D. and O. Lilleland (1946). Determination of potassium and sodium in plant material and soil extracts by flame photometry. Proc. Amer. Soc. Hort. Sci., 48:341-346.

Chen, Y. and T. Aviad (1990). In Humic substances in soil and crop sciences: Selected readings, Effects of humic substances on plant growth, eds MacCarthy P., Clapp C.E., Malcolm R.L., Bloom P.R., et al. (Amer. Soc. Agronomy, Madison, WI), pp 161-186.

Chen, Y, De Nobili M and Aviad T (2004). Stimulatory effect of humic substances on plant growth. In 'Soil organic matter in sustainable agriculture'. (Eds F Magdoff, RR Weil) pp. 103-130. (CRC Press: Boca Raton, FL). (C.F. Eid, 2013).

Cholewa, U.S. (2008). Effect of foliar and soil application of copper on the level and quality of winter rapeseed yields. J. Elementol, 13(4): 615623.

Danilcenko, H., E. Jariene, P. Aleknaviciene and M. Gajewski (2008). Quality of Jerusalem artichoke (Helianthus tuberosus L) tubers in relation of storage conditions. Hort.Agrobot. Cluj., 36(2):23-27.

Eid, K. (2013). Field applications of some bioagents and safety chemicals to control stem rot disease of Jerusalem artichoke (Helianthus tuberosus L.). J. Appl. Sci. Res., 9(11): 5825-5834.

El-Desuki, M. (2004). Response of onion plants to humic acid and mineral fertilizers application. Annl. Agric. Sci., 42:1955-1964.

El-Dissoky R.A. and A.E.S. Abdel-Kadar (2013) Effect of boron as a foliar application on some potatoes cultivars under Egyptian alluvial soil conditions. Res. J. Agric. and Biol. Sci., 9 (5): 232-240. 
El Sayed Hameda, E.A., A. Saif El Dean, S. Ezzat, A.H.A. El Morsy (2011). Responses of productivity and quality of sweet potato to phosphorus fertilizer rates and application methods of the humic acid. Int. Res. J. Agric. Sci. Soil Sci., 1:383-393.

El-Shabrawy, R. A., A.Y. Ramadan and Sh. M. El-Kady (2010). Use of humic acid and some biofertilizers to reduce nitrogen rates on cucumber (cucumis sativus L.) in relation to vegetative growth, yield and chemical composition. Plant Production, Mansoura University, 1(8): $1041-1051$.

El-Zohiri, S.S.M. and M.E.A. Youssef (2015). Response of Jerusalem artichoke to cut off irrigation before harvest and fertilization with $\mathrm{Ca}$, $\mathrm{Mg}$ and B. J. Product. \& Dev., 20(1): $61-81$.

Erik, B., G. Feibert, C.C. Shock and L.D. Saundres (2000). Evaluation of humic acid and other non conventional fertilizer additives for onion productivity. Malheur Experiment Station, Oregon State University Ontario.

Graham, D.R. (1983). Effects of Nutrients Stress on Susceptibility of Plants to Disease with Particular Reference to the Trace Elements." Advances in Botanical Res., 10: 221-76.

Hafez, M. Magda (2003). Effect of some sources of nitrogen fertilizer and concentration of humic acid on the productivity of squash plant. Egypt. J. Appl. Sci., 19:293-309.

Hartwigson, J.A. and M.R. Evans (2000). Humic acid seed and substrate treatments promote seedling root development. Hort. Science, 35:1231-1233.

Jackson, M.L. (1973). Soil Chemical Analysis. Printice-Hall of India. Privat Limited, New Delhi.

Jafari-Jood, S., A.H. Shiranirad, J. Daneshian and A. Rokhzadi (2013). Effects of nitrogen application and spraying of boron and manganese on growth traits of two potato cultivars. International Journal of Biosciences, 3 (9): 298-303.

James, C.S. (1995). Analytical Chemistry of Foods. Blokie Academic \& Professional, London.

Koch, F.G. and T.L. McMeckin (1924). A new direct nesslerization micro-Keldahl method and a modification of the Nessler-Folin reagent for ammonia. J. Amer. Chem. Soc., 46: 2066.

Liu, C.R., J. Cooper and D.C. Bowman (1998). Humic acid application affects photosynthesis, root development and nutrient content of creeping bent grass. Hort. Sci., 33: 1023-1025. 
Mahmoud Asmaa, R., M. Hafez Magda (2010). Increasing productivity of potato plants (Solanum tubersoum L.) by using potassium fertilizer and humic acid application. Int. J. Acad. Res., 2:83-88.

Malcolm, R.E. and D. Vaughan (1979). Effects of humic acid on invertase activities in plant tissues and their interaction with an invertase inhibitor. Soil Biol. Biochem., 11: 65-72.

Marie, A.I. and R.S. Toma (2011). Effect of planting density, seed tuber size and boron application on potato yield and chemical composition. Jordan J. of Agric. Sci., 6 (3): 445-467.

Marschner, H. (2013). Mineral Nutrition of Higher Plants. $3^{\text {th }}$ Ed. Academic Press, Harcourt Brace and Company, Publishers. London, New York, Tokyo, pp 864.

Mengel, K. and E.A. Kirkby (1978). "Principles of Plant Nutrition", International Potash Institute, Bern, Switzerland.

Mortvedt, J.J., F.R. Cox, chair, L. Shuman and R.M. Welch. (Eds) (1991). Micronutrients in Agriculture, $2^{\text {nd }}$ Edition. Soil Science Society of America, Madison, WI. 760 p.

O'Donnell, R.W. (1973). The auxin-like effects of humic preparations from leonardite. Soil Sci., 116: 106-112.

Orafti, L. (2005). Active food scientific monitor. An Orafti Newsletter, $\mathrm{Nr}$ 12- spring 2005. http://www.prebiotic.ca/pdf/Orafti 012.pdf.

Puzina, T.I., (2004). Effect of zinc sulfate and boric acid on the hormonal status of potato pla nts in relation to tuberization. Russian Journal of Plant Physiology, 51(2): 209-214.

Qualls, R.G. (2004). Biodegradability of humic substances and other fractions of decomposing leaf litter. Soil Science Society of America J. , 68: 1705-1712.

Reisenauer, H.M., L.M. Walsh and R.G. Hoeft, 1973. Testing soils for sulphur, boron, molybdenum and chlorine, pp. 173-200. In: L. M. Walsh and J. D. Beaton: Soil Testing and Plant Analysis. Soil Soc. Of America Inc., Madison/ Wisconsin. (C.F. El-Dissoky and AbdelKadar, 2013).

Selim, E.M., S.I. Shedeed, F.F. Asaad, A.S. El-Neklawy (2011). Interactive effects of humic acid and water stress on chlorophyll and mineral nutrient contents of potato plants. J. Appl. Sci. Res., 7:531537.

Snedecor, G.W. and W.G. Cochran (1980). Statistical Methods. $7^{\text {th }}$ Ed., Iowa State Univ., Press, Ames., Iowa, USA. 
Troug, E. and A. H. Meyer (1939). Improvement in deiness colorimetric method for phosphorus and arsenic. Ind. Eng. Chem. Anal. Ed., 1: 136-139.

Verlinden, G., B. Pycke, J. Mertens, F. Debersaques, K. Verheyen, G. Baert, J. Bries, G. Haesaert (2009). Application of humic substances results in consistent increases in crop yield and nutrient uptake. J. Plant Nutr., 32:1407-1426.

Wills, R.B.H.. T.H.Lee, D. Gerham, W.B. McGlesson and E.G. Hall (1981). Post harvest An Introduction To Physiology And Handling Of Fruits And Vegetables. Inc Westport, Connecticut. 163 pp

Winton, A.L. and K.B. Winton (1958). The Analysis Of Foods. John Wiley and Sons. Inc. London.pp.857.

Yao, S. (2014). Effects of copper-based foliar fertilizer and controlled release fertilizer on growth and leaf protective enzyme activities of pepper. Journal of Plant Nutrition and Fertilizer, 20 (5): 1221-1233.

Zhang, X., E.H. Ervin and R.E. Schmidt (2003). Physiological effects of liquid applications of a seaweed extracts and humic acid on creeping. J. Amer. Soc. Hort. Sci.,128(4): 492-496. 
تأثير المعاملة بالبورون والنحاس وحامض الهيوميك على النمو الخضري

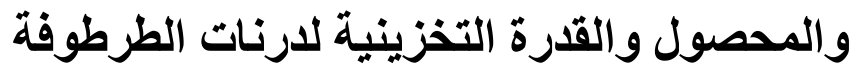

محمود محمد سامي ، نجوى عبدالغني محمد ، مرفت جلال عبدالعزيز

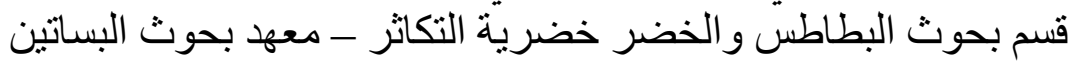

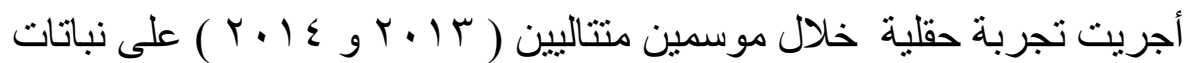

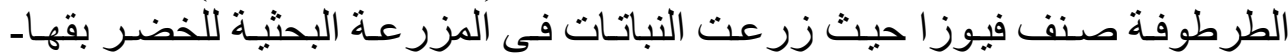

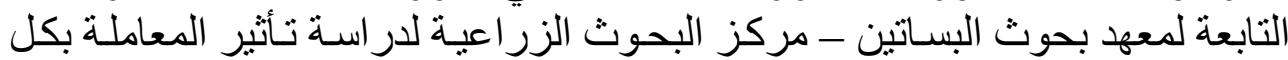

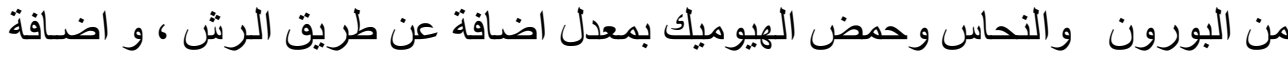

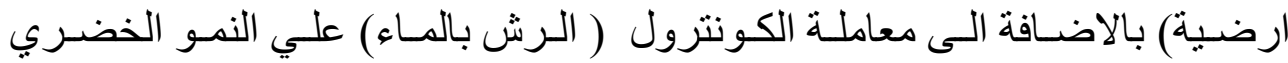

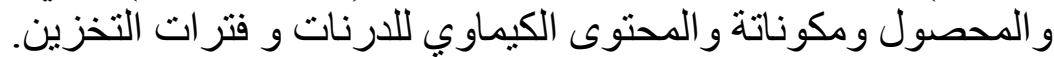

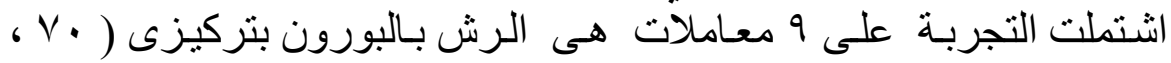

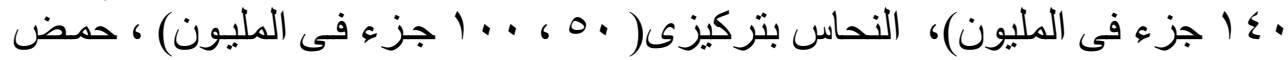

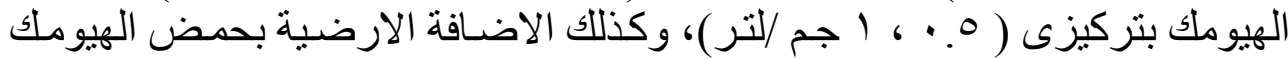

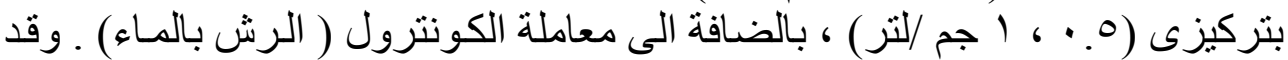

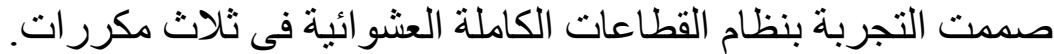

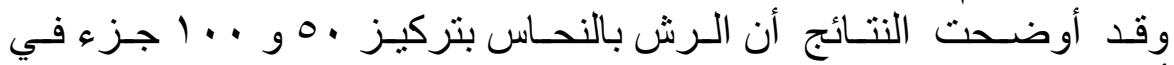

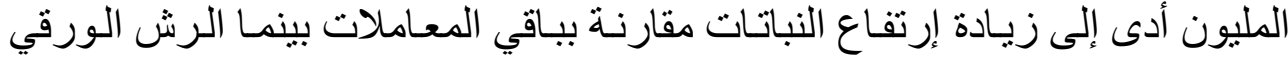

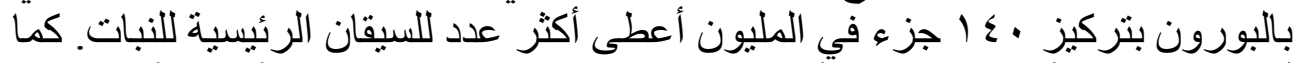

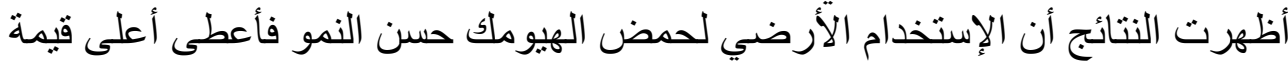

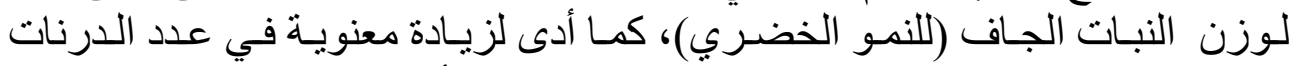

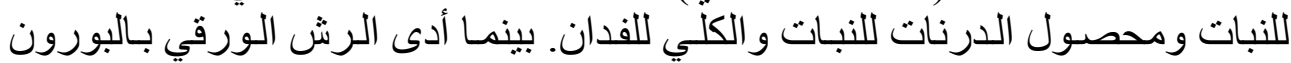

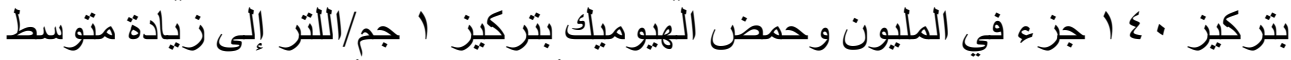

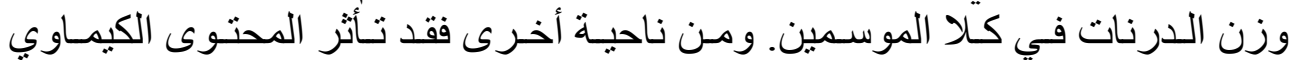

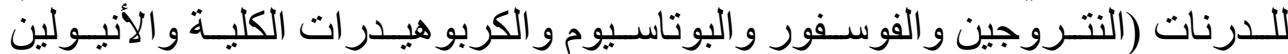

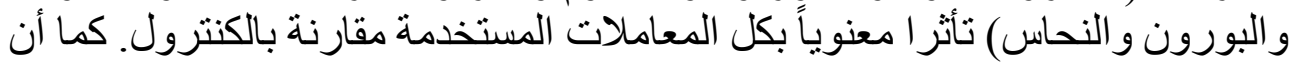

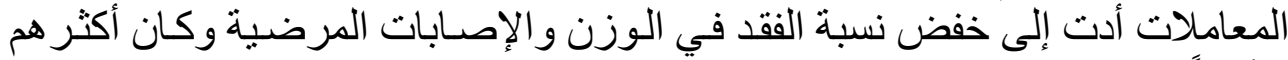

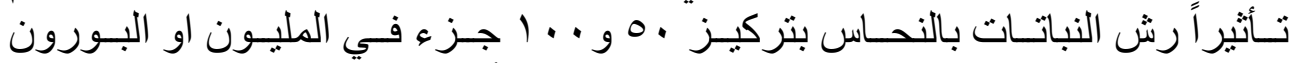

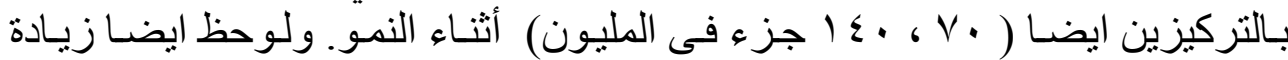

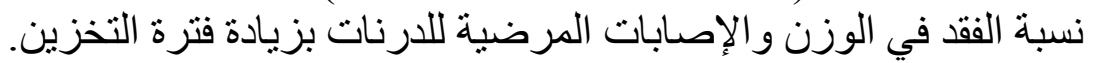

